\title{
Hepatitis B Virus Mutants with Precore-Region Defects in Two Babies with Fulminant Hepatitis and Their Mothers Positive for Antibody to Hepatitis B e Antigen
}

\author{
SOUSUKE TERAZAWA, MINEO KOJIMA, TATSURU YAMANAKA, SHIGERU YOTSUMOTO, \\ HIROAKI OKAMOTO, FUMIO TSUDA, YUZO MIYAKAWA, AND MAKOTO MAYUMI \\ Department of Pediatrics, Prefectural Gero Hospital, Gifu-Ken 509-22; Kojima Clinic, Gifu-Ken 500; the \\ Department of Pediatrics, Sapporo Medical College, Hokkaido 060; Immunology Division, Jichi Medical School, \\ Tochigi-Ken 329-04; Section of Immunology, Kitasato Institute, Tokyo 108; and Mita Institute,
}

Tokyo 108, Japan

\begin{abstract}
Clones of hepatitis B virus (HBV) DNA were propagated from sera of two babies who developed neonatal fulminant hepatitis $B$, as well as from sera of their mothers who carried HBV with antibody to hepatitis $B$ e antigen, and the precore-region sequences were determined. A point mutation from guanine to adenine, converting codon 28 for tryptophan (TGG) to a stop codon (TAG), was detected in 18 of $20 \mathrm{HBV}$ DNA clones from mother and all 31 clones from baby in one family, and invariably in 55 clones from mother and three clones from baby in the other family. These results indicate that HBV mutants defective in the precore region in some carrier mothers with antibody to hepatitis $B$ e antigen may transmit fulminant hepatitis B to their babies. (Pediatr Res 29: 5-9, 1991)
\end{abstract}

\section{Abbreviations}

ALT, alanine aminotransferase anti-HBe, antibody to hepatitis $B$ e antigen anti-HBs, antibody to hepatitis $B$ surface antigen anti-HDV, antibody to hepatitis delta virus

HBeAg, hepatitis B e antigen

HBsAg, hepatitis B surface antigen

HBV, hepatitis B virus

IgM anti-HBc, antibody against hepatitis B core antigen of Ig M class

nt, nucleotide

PCR, polymerase chain reaction

Individuals infected with $\mathrm{HBV}$ have $\mathrm{HBsAg}$, representing the viral envelope, in the circulation. In addition, they have either $\mathrm{HBeAg}$, which is closely related to the viral nucleocapsid (1), or anti-HBe. The presence of $\mathrm{HBeAg}$ or anti-HBe in the serum is significant for the immunopathologic status of hosts and also for the biology of HBV infecting them (2).

Perinatal HBV infection, resulting in a persistent carrier state of babies, is transmitted by carrier mothers who are positive for $\mathrm{HBeAg}(3,4)$. Most babies born to them harbor HBV without symptoms; some develop a spectrum of hepatic disease ranging from chronic hepatitis to hepatocellular carcinoma later in their lives.

Received May 3, 1990; accepted August 30, 1990.

Correspondence: Dr. Makoto Mayumi. Immunology Division, Jichi Medical School, Minamikawachi-Machi, Tochigi-Ken 329-04. Japan.
By contrast, babies born to carrier mothers with serum anti$\mathrm{HBe}$, rarely, if ever, develop a persistent carrier state. Some of them, however, contract acute HBV infection with or without clinical symptoms $(5,6)$. Although infrequently, fulminant hepatitis B develops in babies born to asymptomatic carrier mothers $(7-13)$, and anti-HBe in sera of implicated mothers has attracted increasing attention (11-13).

Recent advances in the molecular biology of HBV have established the biosynthetic pathway of $\mathrm{HBeAg}$. In HBV DNA, the $C$ gene coding for the nucleocapsid protein is preceded in phase by the precore region composed of $87 \mathrm{bp}$ and capable of encoding 29 amino acid residues (14). The product of the precore region and the $C$ gene forms the precursor of $\mathrm{HBeAg}$. The precursor is directed to the endoplasmic reticulum membrane by means of the signal peptide that is encoded within the precore region. There the precursor receives proteolytic cleavage and loses amino-terminal and carboxy-terminal parts. Resulting $\mathrm{HBeAg}$ protein, made of 159 amino acid residues, is secreted from hepatocytes into the circulation $(15,16)$.

HBV DNA clones were propagated, after amplification by PCR (17), from sera of two babies with neonatal fulminant hepatitis B and their mothers who carried HBV with serum anti$\mathrm{HBe}$. The great majority of HBV DNA clones from mothers, as well as all clones from their babies, was found to possess a precore-region defect that inhibited the synthesis and secretion of $\mathrm{HBeAg}$. On the basis of these observations, some HBV mutants with precore-region defects in carrier mothers positive for anti-HBe would be particularly virulent and transmit fulminant hepatitis $\mathrm{B}$ by the perinatal infection.

\section{MATERIALS AND METHODS}

Subjects. Case 1 in family A was a boy who developed high fever, convulsion, and disturbance of consciousness 2 mo after birth. Liver was not palpable. ALT was $5200 \mathrm{IU} / \mathrm{L}$ and bilirubin $5.2 \mathrm{mg} / 100 \mathrm{~mL}$. He had coagulopathy with prothrombin less than $10 \%$ and fibrinogen $39 \mathrm{mg} / 100 \mathrm{~mL}$. His serum was negative for $\mathrm{HBsAg}$, and positive for anti-HBs with a hemagglutination titer of $2^{6}$. Neither $\mathrm{HBeAg}$ nor anti-HBe was detected, and anti$\mathrm{HDV}$ was negative. He was positive for $\mathrm{IgM}$ anti-HBc, and the diagnosis of fulminant hepatitis B was established (18). His mother carried HBV asymptomatically without elevated levels of ALT. Her serum contained $\mathrm{HBsAg}$ with a hemagglutination titer of $2^{5}$ and HBV DNA at a level of $1-5 \mathrm{pg} / 50 \mu \mathrm{L}$, and was positive for anti-HBe. After admission, hepatic encephalopathy of the baby aggravated to coma with serum ammonium $300 \mu \mathrm{g} /$ $100 \mathrm{~mL}$. He responded to exchange transfusion, $700 \mathrm{~mL}$ each 
four times, and infusion with branched-chain amino acids. On the 8 th $\mathrm{d}$ after the onset, consciousness started to improve with ammonium decreasing to $101 \mu \mathrm{g} / 100 \mathrm{~mL}$. Liver biopsy performed on the 15 th $\mathrm{d}$ disclosed submassive necrosis of hepatocytes. The absence of fine droplets of lipid in a pan-lobular distribution, taken along with increased matrix density of mitochondria on electron microscopic observations, ruled out Reye syndrome. ALT levels gradually decreased, and he recovered completely 3 mo after the admission.

Case 2, a boy in family B, developed signs and symptoms of fulminant hepatitis 2 mo after birth. On admission, he was generally icteric with serum bilirubin $10.6 \mathrm{mg} / 100 \mathrm{~mL}$, and ALT $3130 \mathrm{IU} / \mathrm{L}$. Coagulopathy was evident with prothrombin less than $10 \%$ and fibrinogen $36 \mathrm{mg} / 100 \mathrm{~mL}$. Liver biopsy was not performed. He had disturbed consciousness with ammonium $104 \mu \mathrm{g} / 100 \mathrm{~mL}$. He was negative for $\mathrm{HBsAg}$, and positive for anti-HBs with a titer of $2^{3}$. He was positive for anti-HBe. His serum revealed $\mathrm{IgM}$ anti-HBc for the diagnosis of fulminant hepatitis B. Anti-HDV was negative. His mother had been diagnosed with type B liver cirrhosis, histologically proven by liver biopsy performed 5 y before the delivery, and had moderately high ALT levels. Her serum taken $31 / 2$ mo before delivery contained HBsAg with a titer of $2^{11}$ and HBV DNA at a level of 1$5 \mathrm{pg} / 50 \mu \mathrm{L}$, and was positive for anti-HBe. The baby responded to treatments including exchange transfusion and recovered completely 3 mo after admission.

Serologic testing for HBV markers. HBsAg and anti-HBs were determined by passive hemagglutination with commercial assay kits (MyCell, Institute of Immunology Co., Ltd., Tokyo, Japan). The results were expressed by the highest 2 -fold dilution of test sera $\left(2^{\mathrm{N}}\right)$ that induced a positive reaction. $\mathrm{HBeAg}$ and anti-HBe were determined with solid-phase enzyme immunoassay kits ( $\mathrm{HBeAg} / \mathrm{Ab} \mathrm{EIA}$, Institute of Immunology). IgM anti-HBc was determined by solid-phase enzyme immunoassay after the method described previously (19). Anti-HDV was determined by commercial RIA kits (Abbott Laboratories, North Chicago, IL). HBV DNA was detected by dot blot hybridization (20), and was semiquantitated by comparing the blot with those of controls with known HBV DNA levels.

Amplification of precore region by $P C R$ and determination of $n t$ sequence. HBV DNA was isolated from $100 \mu \mathrm{L}$ of serum by the method described previously (21) and was dissolved in $20 \mu \mathrm{L}$ of Tris- $\mathrm{HCl}$ buffer $(10 \mathrm{mM}, \mathrm{pH} 8.0)$ containing $1 \mathrm{mM}$ EDTA. HBV DNA fragments (nt 1653-1972) including the precore region (nt 1814-1900) were amplified, with appropriate oligonucleotide primers (21), by the method of Saiki et al. (17). Amplification was performed for 30 cycles in a $100-\mu \mathrm{L}$ reaction volume with use of a Gene Amp DNA amplification reagent kit (Perkin-Elmer Cetus, Norwalk, CT).

HBV DNA amplified by PCR was digested with EcoRI and Hincll (Takara Biochemicals, Kyoto, Japan), and the resulting fragment of $283 \mathrm{bp}$, representing nt 1682-1964 and including the precore region (nt 1814-1900), was cloned into M13 mpl 1 phage vector (Amersham Japan, Tokyo, Japan). The nt sequence of the precore region was then determined by the dideoxy-chain termination method (22).

\section{RESULTS}

The results of sequencing the precore region of $\mathrm{HBV}$ DNA clones from two mother-baby pairs are given in Table 1 along with serum marker of $\mathrm{HBV}$ infection. For family $\mathrm{A}$, sera obtained from mother and her baby on the 16th $d$ of admission were tested. For family B, three sera obtained from mother during 15 mo covering the delivery were tested, along with the serum obtained from her baby on the 7 th admission day. Eighteen of 20 (90\%) HBV DNA clones from mother in family A revealed defects in the precore region, whereas all 31 clones from her baby were precore-defective. In family B, all $55 \mathrm{HBV}$ DNA clones from serial sera from mother, as well as all three clones from her baby, disclosed defects in the precore region.

Nucleotide sequences of the precore region, along with deduced amino acid sequences, are depicted for HBV DNA clones from mother-baby pairs in families A and B (Fig. 1). The precoreregion sequence of a nondefective HBV DNA clone is indicated at the top; the same sequence, with minor substitutions of nt not affecting the function of precore-region product, was displayed by HBV DNA clones from 14 sera from persistent carriers positive for $\mathrm{HBeAg}(21,23)$. The majority of HBV DNA clones from mother and all clones from baby in family $A$, as well as all clones from mother and baby in family $B$, disclosed a point mutation from guanine to adenine at $\mathrm{nt} 83$ in the precore region, converting codon 28 for tryptophan (TGG) to a stop codon (TAG).

In both families, HBV DNA clones from mother were heterogeneous, while those from baby were homogeneous and identical in sequence to one kind of precore-defective clone from mother. Of $20 \mathrm{HBV}$ DNA clones from mother in family A, 15 (75\%) had stop codon 28 along with codon 9 for valine, rather than isoleucine, in the precore region (Fig. 1, a). Among the remaining clones, three (15\%) had stop codon 28 (Fig. $1, b$ ) and two $(10 \%)$ were not defective (Fig. 1, c). All 31 clones from baby displayed stop codon 28 (Fig. $1, d$ ) with precore-region sequences identical to those of three clones from his mother (Fig. 1, b).

All $45 \mathrm{HBV}$ DNA clones from mother in family $\mathrm{B}$, propagated from her serum taken $3 \frac{1 / 2}{2}$ o before delivery, possessed a G-toA point mutation at nt 83 in the precore region (Fig. $1, e$ ). Among them, $19(42 \%)$ had an additional point mutation, from adenine to thymine, at nt 33 (Fig. $1, f$ ) that did not change codon 11 for serine (TCA or TCT). Of 10 clones propagated from two sera of the mother, taken after delivery, one had the sequence (Fig. $1, e$ ) and the remaining nine had the sequence (Fig. 1, $f$ ). All clones from her baby had stop codon 28 with nt 33 of $T$ (Fig. $1, g$ ), and were identical in sequence to one kind of clone from his mother (Fig. $1, f$ ).

\section{DISCUSSION}

Although uncommon, neonatal fulminant hepatitis is a serious disease characterized by elevated levels of serum bilirubin during the earliest months of life and a high mortality. Etiology of childhood fulminant hepatitis is most commonly a complication of viral hepatitis, of which over $50 \%$ is associated with HBV infection (24). Fulminant hepatitis $B$ is suspected by the detection of $\mathrm{HBsAg}$ or anti-HBs in the serum and diagnosed by high-titered IgM anti-HBc (18). An exaggerated immune response of the host to HBV-related antigens has been proposed as the pathogenesis of fulminant hepatitis $B(25,26)$. Combined infections with HBV and hepatitis delta virus are known to increase the risk of developing fulminant hepatitis (27).

Neonatal fulminant hepatitis B clusters in babies born to certain carrier mothers $(9,10)$. Remarkably, it tends to develop in babies born to carrier mothers with serum anti-HBe (11-13). These lines of evidence strongly indicate that particularly virulent strains of $\mathrm{HBV}$, possibly associated with serum anti-HBe, would transmit fulminant hepatitis $B$ from mother to baby in the perinatal period.

HBV mutants with precore-region defects, incapable of directing the synthesis and secretion of $\mathrm{HBeAg}$, gradually prevail and finally replace predecessor, nondefective $\mathrm{HBV}$ in persistent carriers who seroconvert from $\mathrm{HBeAg}$ to anti-HBe (21). To date, at least 25 carriers positive for anti-HBe have been found to possess HBV mutants with precore-region defect, whereas such mutants were not detected in 20 carriers with serum $\mathrm{HBeAg}$; five carriers who were seroconverting from $\mathrm{HBeAg}$ to anti-HBe harbored both wild-type HBV and precore-defective mutants $(21,23,28)$. Elimination of hepatocytes harboring nondefective HBV with the surface expression of $\mathrm{HBeAg}$, by humoral and cellular immune responses of the host against $\mathrm{HBeAg}$, is postulated as the 
Table 1. Defects in precore region of $H B V$ DNA clones from two pairs of mother and baby with neonatal fulminant hepatitis $B^{*}$

\begin{tabular}{|c|c|c|c|c|c|}
\hline & \multirow[b]{2}{*}{ Date of cloning } & \multirow{2}{*}{$\begin{array}{l}\text { HBsAg titer } \\
\quad\left(2^{\mathrm{N}}\right)\end{array}$} & \multirow{2}{*}{$\begin{array}{l}\mathrm{HBeAg} \text { or } \\
\text { anti-HBe }\end{array}$} & \multicolumn{2}{|c|}{$\begin{array}{l}\text { Defects in precore } \\
\text { region of HBV DNA }\end{array}$} \\
\hline & & & & + & - \\
\hline \multicolumn{6}{|l|}{ Family A } \\
\hline Mother & Mar. 23, 1981 & 5 & Anti-HBe & 18 & 2 \\
\hline Baby & Mar. 23, 1981 & $\S$ & Anti-HBe & 31 & 0 \\
\hline \multicolumn{6}{|l|}{ Family B } \\
\hline \multirow[t]{3}{*}{ Mother } & Dec. 24,1987 & 11 & Anti-HBe & 45 & 0 \\
\hline & Nov. 10,1988 & 9 & Anti-HBe & 3 & 0 \\
\hline & Mar. 16, 1989 & 9 & Anti-HBe & 7 & 0 \\
\hline Baby & Apr. 7,1988 & $\S$ & Anti-HBe & 3 & 0 \\
\hline
\end{tabular}

* HBV DNA clones were propagated from sera of mother and baby with perinatal fulminant hepatitis $B$ and sequenced for the precore region. $\dagger$ Point mutation from guanine to adenine at $n t 83$, converting codon 28 for tryptophan (TGG) to a stop codon (TAG).

$\S$ Anti-HBs was detected.

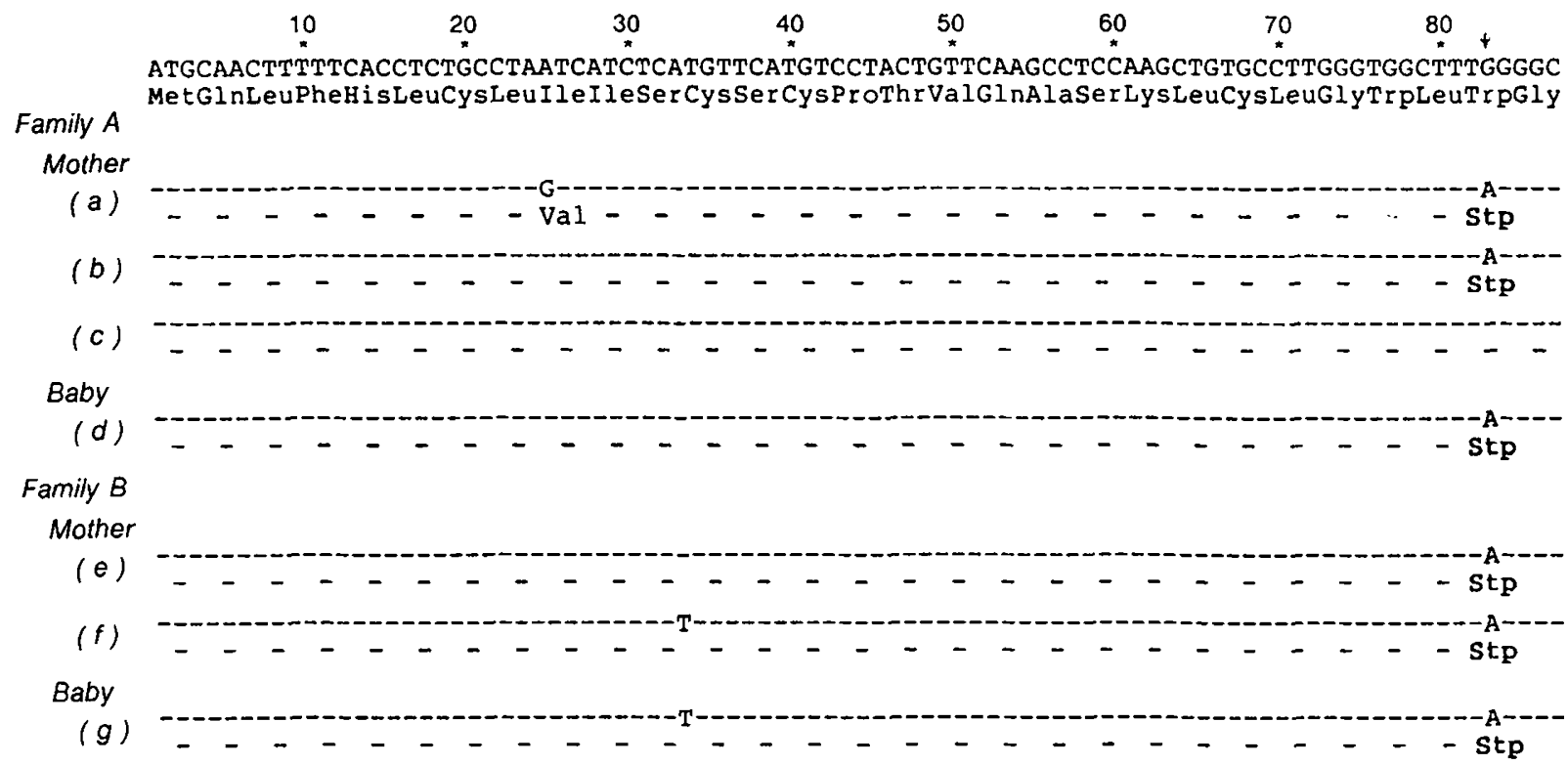

Fig. 1. Nucleotide and deduced amino acid sequences of the precore region. The sequences of nondefective clones $(21,23)$, with the capacity to direct the synthesis and secretion of $\mathrm{HBeAg}$, are indicated at the top. The sequences of $\mathrm{HBV}$ DNA ciones from sera of mother and baby in families $\mathrm{A}$ and $\mathrm{B}$ are given below. HBV DNA clones from babies were homogeneous $(d$ and $g$ ), all with stop codon 28 , whereas those from mothers were heterogeneous $(a-c, e$, and $f)$ and some of them were without precore-region defects $(c)$. The arrow indicates $\mathrm{nt} 83$ that is either guanine, contributing to codon 28 for tryptophan (TGG) in nondefective clones, or adenine, forming a part of stop codon (TAG) in precore-defective clones.

mechanism for the shift from predecessor, nondefective $\mathrm{HBV}$ to mutants with precore-region defects $(21)$.

The precore-region sequences were determined for HBV DNA clones from sera of two babies with neonatal fulminant hepatitis $B$ and their mothers who carried HBV with serum anti-HBe. A recently introduced technique for amplifying desired DNA sequences by PCR (17) was particularly useful in propagating HBV DNA clones from sera of babies without detectable $\mathrm{HBsAg}$ and positive for anti-HBs.

A point mutation from guanine to adenine at $\mathrm{nt} 83$ in the precore region, converting codon 28 for tryptophan (TGG) to a stop codon (TAG), was invariably observed in $\mathrm{HBV}$ DNA clones from sera of mother and baby in family B, and in $90 \%$ of clones from mother and all clones from her baby in family $A$.

Heterogeneous HBV DNA clones, most with precore-region defects, were propagated from sera of mothers, and homogeneous clones, all with precore-region defects, were obtained from sera of their babies. This indicates that diverse mutations, in addition to the most prevalent G-to-A point mutation at nt 83 , would have occurred in the precore region of HBV strains in the carrier mothers who would have had seroconverted from $\mathrm{HBeAg}$ to anti-HBe. Only one of the strains with a precore-region defect would have been transmitted to their babies perinatally and induced fulminant hepatitis $\mathbf{B}$.
Anti-HBe detected in the baby in family $\mathrm{B}$, who were infected with precore-defective HBV mutants, without capacity to encode $\mathrm{HBeAg}$, requires an explanation. Anti-HBe in this baby would have been transported from his mother through the placenta or it might have been raised by him against the $C$-gene product, which is produced by a biosynthetic pathway distinct from $\mathrm{HBeAg}$ and assembles to make core particles $(15,16)$. The $C$ gene product has antigenic determinants of $\mathrm{HBeAg}$, in addition to those of hepatitis B core antigen (1); a rabbit raised anti-HBe, as well as anti-HBc, when it was immunized with the $C$-gene product (29).

On the basis of results obtained, HBV mutants defective in the precore region would have been transmitted from mothers to babies, and induced neonatal fulminant hepatitis B. The lack of hepatitis delta virus infection in afflicted babies would stand in support of this view. To establish the causal relationship between precore-defective HBV mutants and fulminant hepatitis $\mathrm{B}$, however, additional mother-baby pairs with perinatal transmission of fulminant hepatitis B would have to be examined, along with adult cases of posttransfusion or sporadic fulminant hepatitis B. It is necessary, also, to accumulate sequence data on HBV DNA clones from $\mathrm{HBeAg}$-positive mothers and anti-HBepositive mothers whose babies do not develop fulminant hepatitis B. 
Neonatal fulminant hepatitis B is reported in babies born to carrier mothers who were $\mathrm{HBeAg}$-positive and to those without detectable $\mathrm{HBeAg}$ or anti-HBe in the serum $(11,12)$. There still is a possibility that precore-defective HBV mutants would have induced fulminant hepatitis B in these babies. In view of a gradual shift from nondefective $\mathrm{HBV}$ to precore-defective mutants along seroconversion from $\mathrm{HBeAg}$ to anti-HBe (21), these carrier mothers, implicated in the transmission, might have harbored precore-defective mutants, as well as nondefective $\mathrm{HBV}$, even in the presence of $\mathrm{HBeAg}$ or without detectable $\mathrm{HBeAg} / \mathrm{anti}-\mathrm{HBe}$.

In sera from individuals persistently infected with $\mathrm{HBV}$, serum $\mathrm{HBeAg}$ signals active replication of $\mathrm{HBV}$ with high infectivity, whereas anti-HBe denotes inactive replication with low infectious activity (2). There appear to be exceptions to this general rule, however. Sera from some patients with type B chronic active hepatitis contain high levels of HBV DNA, albeit they are positive for anti-HBe $(30,31)$. HBV DNA clones propagated from sera of patients with this disease are defective in the precore region and incapable of directing the synthesis and secretion of $\mathrm{HBeAg}$ $(28,32,33)$. There would be HBV mutants with precore-region defects, therefore, that would have a high replicative activity and, when introduced to susceptible hosts, would be able to induce severe hepatitis.

Apparently, neonatal fulminant hepatitis B is transmitted by only a very minor population of carrier mothers with anti-HBe and precore-defective mutants. This would point to factors on the part of HBV, other than precore-region defects, that are responsible for an enhanced virulence. Of possible relevance to this context is the detection of HBV DNA at $1-5 \mathrm{pg} / 50 \mu \mathrm{L}$, standing for approximately $10^{6}$ infectious viruses $/ \mathrm{mL}$, in sera from both mothers implicated in the transmission of fulminant hepatitis B to their babies, despite the fact that they were positive for anti-HBe. It might be worthwhile to compare HBV DNA levels in sera of anti-HBe-positive carrier mothers who transmit fulminant hepatitis $B$ to their offspring against those from such mothers whose babies do not develop fulminant hepatitis B.

Immunoprophylaxis of perinatal $\mathrm{HBV}$ infection, especially in districts of high endemicity, has been primarily indicated to babies born to $\mathrm{HBeAg}$-positive carrier mothers for the purpose of preventing the development of a persistent carrier state. Apparently, babies born to carrier mothers positive for anti-HBe have to be protected also, lest they develop fulminant hepatitis B. The goal will be readily achieved by combined passive and active immunization, the efficacy of which has been proven in protecting babies born to $\mathrm{HBeAg}$-positive carrier mothers (34, 35).

Acknowledgments. We thank Dr. Masao Umetsu of the Department of Pediatrics, Hokkaido Children's Hospital and Medical Center, and Dr. Satoaki Mima of the Department of Internal Medicine, Kin-Ikyo Sapporo Central Hospital, for valuable serum samples.

\section{REFERENCES}

1. Takahashi K, Akahane $\mathrm{Y}$, Gotanda T, Mishiro S, Imai M, Miyakawa $\mathrm{Y}$, Mayumi M 1979 Demonstration of hepatitis $B$ e antigen in the core of Dane particles. J Immunol 122:275-279

2. Miyakawa Y, Mayumi M 1985 Hepatitis B e antigen and antibody ( $\mathrm{HBeAg} /$ anti-HBe). In: Gerety RJ (ed) Hepatitis B. Academic Press, Orlando, pp 4776

3. Okada K, Kamiyama I, Inomata M, Imai M, Miyakawa Y, Mayumi M 1976 $\mathrm{e}$ antigen and anti-e in the serum of asymptomatic carrier mothers as indicators of positive and negative transmission of hepatitis B virus to their infants. N Engl J Med 294:746-749

4. Stevens CE, Neurath RA, Beasley RP, Szmuness W $1979 \mathrm{HBeAg}$ and anti$\mathrm{HBe}$ detection by radioimmunoassay: correlation with vertical transmission of hepatitis B virus in Taiwan. J Med Virol 3:237-241

5. Shiraki K, Yoshihara N, Sakurai M, Eto T, Kawana T 1980 Acute hepatitis B in infants born to carrier mothers with the antibody to hepatitis $\mathrm{B}$ e antigen. J Pediatr 97:768-770

6. Sinatra FR, Shah P, Weissman JY, Thomas DW, Merritt RJ, Tong MJ 1982 Perinatal transmitted acute icteric hepatitis $B$ in infants born to hepatitis B surface antigen-positive and anti-hepatitis B e-positive carrier mothers. Pediatrics 70:557-559

7. Kattamis CA, Demetrios D, Matsaniotis NS 1974 Australia antigen and neonatal hepatitis syndrome. Pediatrics 54:157-164

8. Dupuy JM, Frommel D, Alagille D 1975 Severe viral hepatitis type B in infancy. Lancet 1:191-194

9. Fawaz KA, Grady GF, Kaplan MM, Gellis SS 1975 Repetitive maternal-fetal transmission of fatal hepatitis B. N Engl J Med 293:1357-1359

10. Mollica F, Musumeci S, Fischer A 1977 Neonatal hepatitis in five children of a hepatitis B surface antigen carrier woman. J Pediatr 90:949-95I

11. Tong MJ, Sinatra FR, Thomas DW, Nair PV, Merritt RJ, Wang DW 1984 Need for immunoprophylaxis in infants born to $\mathrm{HBsAg-positive} \mathrm{carrier}$ mothers who are $\mathrm{HBeAg}$ negative. J Pediatr 105:945-947

12. Delaplane D, Yogev R, Crussi F, Shulman ST 1983 Fatal hepatitis B in early infancy: the importance of identifying $\mathrm{HBsAg}$-positive pregnant women and providing immunoprophylaxis to their newborns. Pediatrics 72:176-180

13. Chang MH, Lee CY, Chen DS, Hsu HC, Lai MY 1987 Fulminant hepatitis in children in Taiwan: the important role of hepatitis B virus. J Pediatr 111:3439

14. Tiollais P, Pourcel C, Dejean A 1985 The hepatitis B virus. Nature 317:489495

15. Bruss V, Gerlich WH 1988 Formation of transmembraneous hepatitis B eantigen by cotranslational in vitro processing of the viral precore protein. Virology 163:268-275

16. Garcia PD, Ou JH, Rutter WJ, Walter P 1988 Targeting of the hepatitis B virus precore protein to the endoplasmic reticulum membrane: after signal peptide cleavage translocation can be aborted and the product released into the cytoplasm. J Cell Biol 106:1093-1104

17. Saiki RK, Gelfand DH, Stoffel S, Scharf SJ, Higuchi R, Horn GT, Mullis KB, Erlich HA 1988 Primer-directed enzymatic amplification of DNA with a thermostable DNA polymerase. Science 239:487-491

18. Shimizu M, Ohyama M, Takahashi $Y$, Udo K, Kojima M, Kametani M, Tsuda F, Takai E, Miyakawa Y, Mayumi M 1983 Immunoglobulin M antibody against hepatitis $B$ core antigen for the diagnosis of fulminant type B hepatitis. Gastroenterology 84:604-610

19. Tsuda F, Naito S, Takai E, Akahane Y, Funuta S, Miyakawa Y, Mayumi M 1984 Low molecular weight (7s) immunoglobulin $M$ antibody against hepatitis $B$ core antigen in the serum for differentiating acute from persistent hepatitis B virus infection. Gastroenterology 87:159-164

20. Scotto J, Hadchouel M, Hery C, Yvart J, Tiollais P, Brechot C 1983 Detection of hepatitis B virus DNA in serum by a simple spot hybridization technique: comparison with results for other viral markers. Hepatology 3:279-284

21. Okamoto H, Yotsumoto S, Akahane Y, Yamanaka T, Miyazaki Y, Sugai Y, Tsuda F, Tanaka T, Miyakawa Y, Mayumi M 1990 Hepatitis B viruses with precore region defects prevail in persistently infected hosts along with seroconversion to the antibody against e antigen. J Virol 64:1298-1303

22. Sanger F, Nicklen S, Coulson AR 1977 DNA sequencing with chain-terminating inhibitors. Proc Natl Acad Sci USA 74:5463-5467

23. Fujiyama A, Miyanohara A, Nozaki C, Yoneyama T, Ohtomo N, Matsubara K 1983 Cloning and structural analyses of hepatitis B virus DNAs, subtype adr. Nucleic Acids Res 11:4601-4610

24. Behrman RE, Vaughan III VC 1987 Nelson Textbook of Pediatrics, 13th Ed. WB Saunders, Philadelphia, pp 844-845

25. Trepo CG, Robert D, Motin J, Trepo D, Sepetjian M, Prince AM 1976 Hepatitis B antigen (HBsAg) and/or antibodies (anti-HBs and anti-HBc) in fulminant hepatitis: pathogenic and prognostic significance. Gut 17:10-13

26. Woolf IL, El Sheikh N, Cullens H, Lee WM, Eddleston ALWF, Williams R, Zuckerman AJ 1976 Enhanced HBsAb production in pathogenesis of fulminant viral hepatitis type B. Br Med J 2:669-671

27. Saracco G, Macagno S, Rosina F, Caredda F. Antinori S, Rizzetto M 1988 Serologic markers with fulminant hepatitis in persons positive for hepatitis B surface antigen. A worldwide epidemiologic and clinical survey. Ann Intern Med 108:380-383

28. Akahane Y, Yamanada T, Suzuki H, Sugai Y, Tsuda F, Yotsumoto S, Omi S, Okamoto H, Miyakawa Y, Mayumi M 1990 Chronic active hepatitis with hepatitis $B$ virus deoxyribonucleic acid and antibody against e antigen in the serum. Disturbed synthesis and secretion of e antigen from hepatocytes due to a point mutation in the precore region. Gastroenterology 99:1113-1119

29. Takahashi K, Imai M, Nomura M, Oinuma A, Machida A, Funatsu G, Miyakawa Y, Mayumi M 1981 Demonstration of the immunogenicity of hepatitis B core antigen in a hepatitis B e antigen polypeptide (P19). J Gen Virol 57:325-330

30. Hadziyannis SJ, Lieberman HM, Karvountzis GG, Shafritz DA 1983 Analysis of liver disease, nuclear $\mathrm{HBcAg}$, viral replication, and hepatitis B virus DNA in liver and serum of $\mathrm{HBeAg}$ vs. anti-HBe positive carriers of hepatitis $\mathrm{B}$ virus. Hepatology 3:656-662

31. Bonino F, Rosina F, Rizzetto M, Rizzi R, Chiaberge E, Tardanico R, Callea $\mathrm{F}$, Verme G 1986 Chronic hepatitis in $\mathrm{HBsAg}$ carriers with serum HBVDNA and anti-HBe. Gastroenterology 90:1268-1273

32. Brunetto MR, Stemler M, Schödel F, Will H, Ottobrelli A, Rizzetto M, Verme G, Bonino F 1989 Identification of HBV variants which cannot produce 
precore derived $\mathrm{HBeAg}$ and may be responsible for severe hepatitis. Ital J Gastroenterol 21:151-154

33. Carman WF, Jacyna MR, Hadziyannis $S$, Karayiannis $P$, McGarvey MJ Makris A, Thomas HC 1989 Mutation preventing formation of hepatitis B

e antigen in patients with chronic hepatitis B infection. Lancet 2:588-59

34. Tada H, Yanagida M, Mishina J, Fujii T, Baba K, Ishikawa S, Aihara S, Tsuda
F, Miyakawa Y, Mayumi M 1982 Combined passive and active immunization for preventing perinatal transmission of hepatitis $B$ virus carrier state. Pediatrics 70:613-619

35. Beasley RP, Hwang LY, Lee GCY, Lan CC, Roan CH, Huang FY, Chen CL 1983 Prevention of perinatally transmitted hepatitis $B$ virus infections with hepatitis B immune globulin and hepatitis B vaccine. Lancet 2:1099-1102
John R. Bower, M.D.

David P. Eisenstat, M.D.

Brett P. Giroir, M.D.

Dorothea D. Jenkins, M.D.

Kathy Ann Merritt, M.D.

Thomas J. Sferra, M.D.

Leslie B. Smoot, M.D

Bryan L. Stone, M.D.

Robert W. Tolan, M.D.

Paul P. Wang, M.D.

\section{Announcement}

\section{THE ASSOCIATION OF MEDICAL SCHOOL PEDIATRIC DEPARTMENT CHAIRMAN, INC.}

proudly announces the

Pediatric Scientist Training Program

\section{Fellows}

Northeast Ohio University George Nankervis, M.D., Ph.D.

University of Toronto Robert Haslam, M.D.

University of Texas Southwestern Charles Ginsburg, M.D.

University of Colorado Gerald Merenstein, M.D.

University of Utah Michael Simmons, M.D.

Ohio State University Grant Morrow, III, M.D.

Harbor/UCLA Delbert Fisher, M.D.

Duke University Samucl Katz, M.D.

Indiana University Richard Schreiner, M.D.

University of Michigan Robert Kelch, M.D.

and gratefully acknowledges the support and sponsorship of National Institute of Child Health and Human Development

The March of Dimes Birth Defects Foundation

The St. Jude Children's Research Hospital

The Cystic Fibrosis Foundation

The William T. Grant Foundation

The American Academy of Pediatrics

The Johnson and Johnson Institute for Pediatric Service 